\title{
LEGISLATIVE POWER OF THE MILITARY OCCUPANT UNDER ARTICLE. 43, HAGUE REGULATIONS
}

\author{
EDMUND H. SCHWENK†
}

Article 43, contained in Part IV, Section III, of the Hague Convention, was designed to limit the legislative power of the military occupant. In the authoritative French text it appears as follows:

"L'autorité du pouvoir légal ayant passé de fait entre les mains de l'occupant, celui-ci prendra toutes les mesures qui dépendent de lui en vue de rétablir et d'assurer, autant qu'il est possible, l'ordre et la vie publics en respectant, sauf empêchement absolu, les lois en vigeur dans le pays." I

While a literal reading seems to indicate that some legislation by the military occupant is permitted, according to one theory ${ }^{2}$ applied in

† Attorney, Office of the Solicitor, Department of the Interior. The opinions expressgd in this article represent the personal views of the author and are not necessarily those of any government department.

1. Strangely enough, the semi-official English translation of Article 43 has never been correct. As given in 2 Scott, The Hague Peace Conferences of 1899 Aid 1907 (1909) 397 , it reads as follows:

"The authority of the legitimate power having in fact passed into the hands

of the occupant, the latter shall take all the measures in his power to restore and ensure, as far as possible, public order and safety, while respecting, unless absolutely prevented, the laws in force in the country."

A comparison of the original French test with the English translation shows that the French term "la vie publique" has been translated into "safety." The literal translation of "la vie publique" is "public life." The actual meaning of "la vie publique" was explained at the Convention of Brussels, session of Aug. 12, 1874, by Baron Lambermont, Belgian reprezantative, as "des fonctions sociales, des transactions ordinaires, qui constituent la vie de tous les jours" (social functions, ordinary transactions which constitute daily life). ACrEs DE LA ConferRence de Broxelles de 1874 (Brussels, 1899) 135; Ministìke des AfFatrs Etrasigères, Actes de la Conférence de Bruxelles de 1874 (Paris, 1874) 23; 4 Martesis, NOUVEAU RECUEIL GENéRAL dE TRATtÉS (2d ser.) (1879) 77.

As a result, the term "civil life" would seem to come closest to the meaning of "la vie publique."

See also 2 Wheaton, International Law (6th Eng. ed., Keith, 1929) 783:

"The words public order and safety do not represent esactly the meaning of

the original 'l'ordre et la vie publics,' which refer also to the entire social and commercial life of the community."

It is therefore suggested that the English version of Article 43 should read as follors:

"The authority of the legitimate power having in fact passed into the hands

of the occupant, the latter shall take all the measures in his power to restore and ensure, as far as possible, public order and civil life, while respecting, unless prevented, the laws in force in the country."

2. See Pillet, Les Lois Actuelles de la Guerre (2d ed. 1S98) 241; Bermier, De L'OCcupation Minitaire (1881) 93; Fenlchenfeld, The Internationill Eco:ionic Law OF BELLIGERENT OCCUPATION (1942) §498, p. 148, n. 3. 
various decisions ${ }^{3}$ the occupant has no right at all to enact legislative measures, and the laws he does impose are mere "commands of the

3. See Cambier v. Lebrun, Belgian Ct. of Cass., Dec. 4, 1919, [1920] i Pasrcrisie Belge 1; Wirliams and Lauterpacht (eds.), Annual Digest of Public international LAw CASEs: 1919-1922 (1932), No. 325, p. 459; 6 HACKworth, Digest of INTERNATIONAL LAw (1943) 396. By an order of the German Governor-General in Belgium of Feb. 10, 1915, arbitral tribunals for rent were set up and the ordinary courts of first instance were given jurisdiction on appeal from decisions of these tribunals. A judgment was rendered in exercise of this jurisdiction by the Court of Namur (April 3, 1917) as first instance. Appellant asked to quash the judgment. His application was dismissed. The Court of Cassation said: "It must be admitted that decisions rendered by courts established under the order of the German Governor-General in Belgium of February 10, 1915, bind the parties. However, these tribunals are not a creation of Belgian law. The decrees of the occupying power, whatever they may be, do not emanate from the exercise of national sovereignty. They havo not the validity of Belgian law, but are merely commands of the enemy military authority, and are not incorporated in the legislation or the institutions of the country." -

See also Postula v. City of Liège, Belgian Ct. of Cass., April 29, 1919, [1919] 1 PasickisiE BELGE 132. See, to the same effect, decisions of the Belgian Ct. of Cass. of Jan. 21, 1918, [1918] 1 id.at 177; April 29, 1919, [1919] 1 id. at 132; Oct. 16, 1919, [1919] 1 id.at 225; Dec. 4, 1919, [1920] 1 id. at 1; Jan. 20, 1920, [1920] 3 id. at 168.

As a result of Cambier v. Lebrun, the officials of the court were forbidden to issue for the purpose of executing judgment copies of the decisions rendered by the courts set up by the occupying power on the ground that such a step would tend to contribute a legal character to acts of force alien to the national sovereignty. Official Circular of Dec. 6, 1919, (1920) 78 LA BELGiQue Judiciaire 12.

In Mathot v. Longué, Belgian Ct. of App., Liège, Feb. 19, 1921, (1921) 79 LA BeLGique JUdiCAIRE 438; WilliaMSS AND LAUTERPACHT, op. cil. supra note 3, No. 329, p. 463; 6 HACKWORTH, op. cit. supra note 3, at 396, a German order of Aug. 8, 1918 prohibited the sale of vegetables before they had been gathered. A bargain of this kind had been made by the parties in this case. Mathot not having performed the contract, Longue brought an action for recission and damages and was successful in the court of first instance. Mathot appealed. He based his appeal chiefly on the invalidity of the contract under the German Order of Aug. 8. The Court of Appeals of Liège dismissed the appeal. It rejected the appellant's contention that due to the ratification of the Hague Convention by Belgium in 1910 the orders of the occupant are not merely commands of the military authority, but laws. The court said:

" 'This inference, logically and legally inadmissible, is based on a false premise-that is to say, the admission . . . that Article 43 of the Hague Convention - conferred upon the occupying Power a positive right to legislate; but . . . it is inaccurate to say that by virtue of the Convention the occupant has been given any portion whatever of the legislative power; . . . it appears from the text of the Convention itself and from the preliminary work that all that was intended ... was to restrict the abuse of force by the occupant and not to give him or recognize him as possessing any authority in the sphere of law.' The law remains the apanage of the national authority exclusively, the occupant possessing de facto power and nothing more. It follows from that, that the Belgian law of 1910 could not and did not recognize the de facto power of the occupant as having the right to legis late.

"Moreover, to admit that the occupying power has any right to legislate . . . would be to create very possibly and frequently an insoluble conflict between the decrees of the legal authority and those issued by the de facto power; this is inadmissible as being contrary to the absolute character of sovereignty. It followed 
military authority of the occupant." The weight of authority, however, recognizes the occupant's right to legislate since the clause "respecting the laws of the country unless absolutely prevented" would be meaningless if the occupant had no legislative power whatsoever. While it seems thus well established that the occupant is not prohibited from legislating under the principles of international law, the necessity of determining the extent to which this power to legislate is limited by Article 43 of the Hague Regulations, raises a number of problems.

\section{Application of the Limitations Imiposed by Article 43}

A literal interpretation of Article 43 seems to indicate that the military occupant is authorized to enact legislative measures only in so far as they restore public order and civil life, i.e., are concerned with the common interest or the interest of the population, and that he is prohibited from legislating in fields other than those designed to restore public order and civil life, i.e., in promotion of his military interests. ${ }^{5}$ Such a limitation of the legislative power of the occupant, hovever, would be inconsistent with the principle expressed in Article 43 that the entire authority of the legislative power has, in fact, passed into the hands of the occupant. ${ }^{6}$

Under a literal construction of Article 43 it might also seem that the limitations imposed on the exercise of legislative power apply only to measures designed to restore public order and civil life, but not to other legislative measures. Most writers on international law, however, take it for granted that the limitations contained in Article 43 govern the entire field of legislation, ${ }^{7}$ and only two, $\mathrm{Hyde}^{8}$ and Meurer, ${ }^{0}$ have recognized the existence of this problem.

from these considerations that the Order of $S$ August 1918, emanating from a de facto power, had no legal value and could not acquire such a value by virtue of the Belgian Law of 1910, and that the Belgian courts could not base their decisions on such a decree."

4. This is the interpretation of the phrase "to restore and ensure public order and civil life" given by Meurer, Die Voel.kerkechthiche Stellung der vous Ferid aesetzTEN GEBIETE (Tübingen, 1915) 23.

5. This is the interpretation of legislative acts not included in the term "restoration of public order and civil life" by MEURER, op. cil. supro note 4, at 23.

6. See Meurer, op. cil. supra note 1 , at 18 .

7. FELCHENFELd, op. cit. supra note $2, \S 324$, p. S9; 2 GarNer, INTERMational LaW AND IHE World WAR (1920) 5; HALl, INTERNational LaW (Sth ed., Higgins, 1924) 465; 2 OPPENHEDS, INTERNATIONAL Law (5th ed., Lauterpacht, 1935) § 169, pp. 349-50; IVILSO:; HaNDbook of INTERNational Law (3d ed. 1939) \& 129, p. 310; Staufienberg, Jerlragliche Beziehungen des Okkupanten zat den Landeseinuohnern (1931) 2 ZEITSCarIFT FUER AUSLAENDISCHES OEFFENTLICHES RECHT UND VOELKERRECET 103.

S. 2 HYDE, INTERNaTIONAL LAW (1922) $§ 690$, pp. 367-S: "Thus in resloring public order and safety he appears to be bound to make serious endeavor to continue in force the 
The history of Article 43 verifies the general view that the limitations were designed to apply to the entire field of legislation. The predecessors of Article 43 are Article 2 and 3 of the Declaration of Brussels of 1874. Article 2 of the Declaration of Brussels reads as follows:

"L'autorité du pouvoir légal étant suspendue et ayant passé de fait entre les mains de l'occupant, celui-ci prendra toutes les mesures qui dépendent de lui en vue de rétablir et d'assurer, autant qu'il est possible, l'ordre et la vie publique." 10

\section{Article 3 provides:}

"A cet effet, il maintiendra les lois qui étaient en vigueur dans le pays en temps de paix, et ne les modifiera, ne les suspendra ni les remplacera que s'il y a nécessite." 11

At the Hague Conference of 1899 an elaborate discussion developed over whether Article 3 of the Brussels Declaration should be retained to protect occupied countries from far-reaching legal changes ${ }^{12}$ or whether it should be eliminated because it concedes to any occupant the right to exercise legislative power even before occupation has taken place. ${ }^{13}$ Various drafts were submitted to reconcile these points of

ordinary civil and criminal laws which do not conflict with the security of his Army or its support, efficacy, and success." (Emphasis supplied.)

9. Meurer, op. cit. supra note 4, at 23: "The Article 43 mentions the requirentent of necessity only for the field of public order and civil life, that is for legislative acts in the common interest or interest of the population. . . . Article 43 leaves a gap for legislative acts in the military interest, which, according to v. Martens' formula, must be filled by the principle of war usage, morals, and humanity. This probably also leads to the effect that such legislative acts must be confined to those which are absolutely necessary." (Translation by author.) 469.

Sec also Davidonis, Some Problems of Military Government (1944) 38 Aus. PoL. Sc1. Rev.

10. "The authority of the legitimate power being suspended and having actually passed into the hands of the occupant, the latter shall take all steps in his power to reestablish and insure, as far as possible, public order and safety." (Translation from Higcins, Tue HaGUE Peace Conference (1909) 273.)

11. "With this object he will maintain the laws which were in force in the country in time of peace, and will only modify, suspend or replace them by others if necessity obliges him to do so." (Translation from HigGiNs, loc. cit. supra note 10.)

12. This position was taken by v. Martens, Russian representative, although it was later discarded by him, and by Lammasch, Austrian representative, as well as by v. Bildt, Swedish-Norwegian representative. See 3 ConfErence INTERnationale de LA PAIX (1899) 113-6, 120; Perris, A History of the Peace Conference at tue Hague (1914) 66; Holls, The Peace Conference at the Hague (1900) 137-8; 2 Meurer, Die Hanger FRIEDENS-KONFERENZ (1907) 209-10.

13. This position was taken by Beernaert, representative of Belgium, v, Marteng, Russian representative, after a change of mind, and Dutch General Den Beer Poortugael. See 3 Conference Internationale de la PaIX (1899) 113; Perris, op. cil, stipra note 12, at 157; 2 MEURER, op. cit. supra note 12, at 207-8. 
view, ${ }^{14}$ but none of them was approved by the Conference. Finally, Bihourd, the representative of France, suggested, ${ }^{15}$ as a matter of compromise, that while Article 3 should be canceled, its spirit should be incorporated into Article 2 by the following clause: "en respectant, sauf empêchement absolu, les lois en vigueur dans le pays." This suggestion was accepted by a vote of twenty-three against one (Japan). ${ }^{10}$

Thus it seems that Article 3 of the Declaration of Brussels retained its character as a general principle even though it became attached to Article 2, which dealt only with the duty of the occupant to restore public and civil life. As a result, the limitations contained in Article 43 of the Hague Regulations apply to the entire field of legislation. Noreover, even under the view that the limitations of Article 43 should be confined to legislative measures designed to restore public order and civil life, it has been suggested that laws enacted in other fields should be governed by limitations arising from war usage, morals and humanity. ${ }^{17}$

Again, a literal interpretation of Article 43 might suggest that the limitations apply only to laws but not to decrees or ordinances. But such a theory, though it has been advanced, ${ }^{18}$ is incompatible both with the purpose of Article 43 and with the fact that the difference

14. Odier, Swiss representative, submitted this draft:

"A cet effet, il maintiendra les lois qui étaient en vigueur dans le pays en temps de paix. Il ne pourra en suspendre l'exécution que dans la mesure et pour le temps où cela sera nécessaire en vue du maintien de l'ordre."

Rolin, representative of Siam, proposed the following draft:

"Les lois existantes restent en vigueur dans le territoire occupe et si l'occupant est amené, par suite des nécessités de la guerre à les modifier, à les suspendre ou a les remplacer, l'effet de cas mesures sera limité a l'étendue et la durie de l'oceupation."

To meet Lammasch's objections against limiting occupation measures for the time of occupation, Rolin submitted a new draft:

"Les lois existantes restent en vigueur dans le territoire occupé et si l'occupant est amené, par suite des nécessités de la guerre, a les modifer, à les suspandre ou d les remplacer, ces mesures n'auront qu'un caractère purement provisoire limité suivant l'étendue et la durée de l'occupation."

3 Conference internationale de la Paix (1S99) 122-3, 126, 164; 2 AIeurer, op. cit. supra note 12, at 228, 230.

15. 3 Conférence INternationale de LA Paix (1899) 127; 2 Mieuner, op. cil. sufto note 12 , at 230.

16. 3 Conférence Internationale de la Paxx (1899) 127; 2 Mieurer, op. cit. suffo note 12 , at 230 .

Motono, the Japanese representative, declined at first to vote for Bihourt's proposal on the ground that Article 2 speaks only of maintenance of public order and civil life, whereas Article 3 expresses a general principle of limiting the legislative power of the occupant. He thought Article 3 would lose its meaning if it would be attached to Article 2. However, due to the efforts of some representatives, MIotono reversed his vote.

17. This construction has been suggested by MIEURER, op. cil. supra note 4 , at 23 .

18. See MEURER, op. cit. supra note 12, at 241. 
between laws on the one hand, and decrees or ordinances on the other, is one of form rather than of substance. ${ }^{19}$

Granting that Article 43 applies to decrees and ordinances as well as to laws, it does not necessarily follow that it applies to "ordinary" as well as to "extraordinary" laws, decrees, and ordinances. At least it was so held in the famous case of Cillekens $v$. Deffaas, ${ }^{20}$ which involved an .order of the German Governor General in Belgium terminating a moratorium previously established by the King of the Belgians for the duration of the war. In an action of debt brought by the plaintiff, the defendant conceded plaintiff's claim, but invoked the moratorium, maintaining that the German Governor's cancellation order was illegal because it was contrary to Article 43. The court, however, gave judgment for plaintiff on the ground that the limitations of Article 43 apply to ordinary laws but not to war measures and that therefore the moratorium had been validly terminated.

Interpretation of the Clause "restore and ensure public order and civil life." Article 43 by its express language confines respect for the existing laws of the occupied country to those measures which are designed "to restore and ensure public order and civil life." At the Convention of Brussels the meaning of "l'ordre" and "la vie publique" was discussed by Baron Lambermont. The record on this point reads as follows:

"M. le baron Lambermont demande ce qu'il faut entendre par ordre. Il y a ordre matériel, civil, social politique. M. le délégué de Belgique présume qu'on a seulement en vue la sécurité ou la sûreté générale; quant à l'expression 'vie publique', il pense qu'il s'agit des fonctions sociales, des transactions ordinaires, qui constituent la vie de tous les jours.

La commission interprète ce mot dans le même sens que $M$. le baron Lambermont. On mettra: 'l'ordre et la vie publics." " 21

This discussion suggests that by "l'ordre" the Convention meant "security or general safety" and by "la vie publique" it thought of "social functions [and] ordinary transactions which constitute daily" life."

While the occupant can restore public order and civil life only when they have been disrupted, he may legislate to ensure them in the absence of any disturbance. Hence the terms "restoration" and "ensurance" are used alternatively rather than jointly. In the case of Ville d'Anvers v. État allemand, ${ }^{22}$ the German-Belgian Arbitration

19. Strupp, Das INTERNationale LANDKRIEGsRECht (1914) 99, n. 2.

20. Cillekens v. DeHaas, Dutch Dist. Ct., Rotterdam, May 14, 1919, Williass AND LAUTERPACHT, op. cit. supra note 3, No. 336, p. 471, 6 HACKWORTH, op. cit. supra note 3, at 395 .

21. Ministere des Affaires Étrangères, Actes de la Confìrence de Bruxelles DE 1874 (Paris, 1874) 23.

22. Ville d'Anvers v. Etat allemand, German-Belgian Mixed Arbitral Tribunal, Oct. 19, 1925, (1925) 5 Recueil des Decisions des Tribunaux ARbitraUx Mixtes 712, 6 HackWORTH, op. cil. supra, at 395-6. 
Tribunal left this question open when it denied the validity of a German decree of February 3, 1915 in Belgium on the ground that there was neither a need for restoration nor one for maintenance of public order and civil life. In the cases of Bochart v. Commillee of Supplies of Corneaux ${ }^{23}$ and De Brabant and Gosselin \%. T. and A. Florant ${ }^{24}$ the Belgian courts reached contrary conclusions in regard to a German decree of August 8, 1918 which had declared roid all purchases of vegetables not yet gathered. Whereas in the Bochart case the Court of Appeals of Liège held that the occupant took his action with a view to regulating and diminishing the exorbitant price of regetables, the Court of Appeals of Brussels declared in the Brabant case that "the German order was not made with a view to ensuring public order and security, but to starving the population."

Thus it follows that, when public order and civil life have remained undisturbed, the validity of legislation under Article 43 depends on whether or not the legislating occupant was motivated by a desire to ensure them. There seems little doubt that the term "to ensure public order and civil life" is not a definite and certain concept, but a notion depending on the circumstances of the particular case. This has been most aptly suggested by Leurquin:

"Article 43 of the Hague Convention of the 18th October, 1907 , concerning military authority in the territory of the enemy State, enjoins upon the occupant to take all measures in his power to ensure public order and safety, 'observing, save where there is absolute hindrance, the laws of the country.' It results from this provision that the occupant is authorized, in case of necessity, to make modifications in the laws. It could not be otherwise. When the occupation is prolonged, and when owing to the war the economic and social position of the occupied country undergoes profound changes, it is perfectly evident that new legislative measures are essential sooner or later." 25

Significance of the Clause "sauf empêchement absolu." Article 43 does not compel the occupant to respect the laws of the occupied country in casès of "empêchement absolu." What does "empêchement absolu" mean? Literally taken, the clause "sauf empêchement absolu" has no

23. Bochart v. Committee of Supplies of Corneux, Belgian Ct. of App., Litige, Feb. 28, 1920, Williasss and LauterPaCHT, op. cit. sitpra note 3, No. 327, p. 462.

24. De Brabant and Gosselin v. T. and A. Florant, Belgian Ct. of App., Brussels, July 22, 1920, WILlIAJIS AND LAUTERPACHT, op. cil. supra note 3, No.328, p. 463.

25. Leurquin, The German Occapalions in Belgium and Arlicle 43 of The Hague Consention of the 18th October 1907 (1916) 1 INr. L. NoTEs 55. See, to the same effect, v. Liszr, DAS VoEL EERRECHT (12th ed., Fleischmann, 1925) $\$ 61$, p. 491: "The longer the occupation lasts, the more comprehensive will be the interference with the administration and legislation of the occupied country for its own sake." (Translation by author.) See also Davidonis, supra note 9 , at 469 . 
meaning at all, since the occupant is never absolutely prevented from respecting the laws of the occupied country. ${ }^{26}$ It takes on meaning only if it is completed by a phrase such as "by necessity," "by the interest of the population," or "by the new order of things." It is therefore not astonishing that the scope of this clause has been stated in different terms. President McKinley, in his order to the Secretary of War on the occupation of Santiago de Cuba by the American forces, speaks of a "new order of things," which justifies changes of legislation of the occupied country. ${ }^{27}$ Hyde states that the occupant is absolutely prevented from respecting the laws of the occupied country if they conflict "with the security of his army or its support, efficacy, and success." ${ }^{28}$ Garner suggests that military security or interests is a test for permissible change of the laws. ${ }^{29}$ Wilson considers the occupant entitled to abrogate the existing laws of the occupied country if they are "detrimental to the occupant." ${ }^{30}$ Oppenheim submits that a change of the laws of the occupant is permissible if "necessitated by [the occupant's] interest," ${ }^{31}$ or "by military necessity." ${ }^{32}$ Feilchenfeld believes that the laws may be changed if the change is "sufficiently justified." "3a Fenwick thinks that the occupant need not respect the laws of the occupied country if they are not "compatible with the existence of a state of war and the safety of the army of occupation." ${ }^{34}$ Stauffenberg regards a change of the laws of the occupied country permissible if it is justified by "necessity of the war, public safety, and welfare of the population." "35 Meurer takes the position that the existing laws in the occupied country may be changed in so far as "unsurpassable military obstacles exist." ${ }^{36} \mathrm{He}$ believes, however, that such "unsurpassable obstacles" will soon turn out to be in existence. ${ }^{37}$

The restoration of public order and civil life aims primarily, if not exclusively, at the interest of the population. ${ }^{38}$ Hence, a construction which confines the term "empêchement absolu" to the military interest of the occupant seems too narrow, if not actually incorrect. Such a

26. FEILCHENFELD, op. cit. supre note $2, \S 325$, p. 89.

27. Order to the Secretary of War, July 18, 1898, reprinted in 7 MOORE, Digest of INTERNATIONAL LA W (1906) 261-3. See also HaLl, op. cit. supra note 7, § 155, p. 560 . .

28. 2 HYDE, op. cit. supra note $8, \S 60$, p. 368 .

29. 2 GARNER, op. cit. supra note 7, at 86 .

30. WiLson, op. cil. supra note $7, \S 129$, p. 315.

31. 2 OPPENHEIM, op. cit. supra note $7, \S 169$, pp. 349-50.

32. Oppenheim, The Legal Relations between an Occupying Power and the Inthabilants (1917) 33 L. Q. REv. 365.

33. FeILCHENFELD, op. cit. supra note $2, \S 325$, p. 89.

34. FENWICK, INTERNATIONAL LAW (1934) 486.

35. Stauffenberg, supra note 7 , at 103 .

36. 2 MEURER, op. cit. supra note 12, at 338.

37. Id. at 238: "Such unsurpassable obstacles, which necessitate a change of law, will. however, soon turn out to exist." (Translation by author.)

38. See note 4 supra. 
construction might even lead to the conclusion-actually drawn by Cavare 39 -that the occupant is barred from suspending and promulgating laws in the interest of the occupied country, a conclusion which seems untenable in view of the fact that an occupation for a more or less considerable period of time necessarily requires a change of the laws in the interest of the population of the occupied country. It is therefore submitted that the term "empêchement absolu" means nothing but "absolute necessity." 40 This interpretation is warranted by the historical fact that the term is merely a rephrasing of the word "necessity" in Article 3 of the Declaration of Brussels. As a result, the occupant, in restoring public order and civil life, must respect the existing law of the occupied country unless he is prevented from doing so by "absolute necessity."

The Rules of Land Warfare ${ }^{41}$ which deal with the legislative power of the United States military forces as occupants ${ }^{42}$ seem to give "empêchement absolu" a narrower construction. Rules 285 and 287 treat

39. Cavaré, Quelques notions générales sur l'occupation pacifique (1924) 31 REv uE Genterale de Drott International Public 352.

40. See MeURER, op. cit. supra note 4, at 237: "Incidentally, Art. 3, Declaration of Brussels, already permitted changes of the laws in case of 'necessity'; but this limitation, expressed at the end of Art. 43, has been emphasized more sharply and more definitely." (Translation by author.)

41. U.S. WAR DEP'T, RULES OF LAND WaRfare (FM 27-10) (1940).

42. Rules 285-288 read as follows:

"285. The lawe in force.-The principal object of the occupant is to provide for the security of the invading army and to contribute to its support and efficiency and the success of its operations. In restoring public order and safety he will continue in force the ordinary civil and criminal laws of the occupied territory which do not conflict with this object. These laws will be administered by the local offcials as far as practicable. All crimes not of a military nature and which do not affect the safety of the invading army are left to the jurisdiction of the local courts.

"286. Power to suspend and promalgate laws.-The military occupant may suspend existing laws and promulgate new ones when the exigencies of the military" service demand such action.

"287. Nature of laws suspended.-The occupant will naturally alter or guspend all laws of a political nature as well as political privileges and all laws which affect the welfare and safety of his command. Of this class are those relating to recruitment in occupied territory, the right of assembly, the right to bear arms, the right of suffrage, the freedom of the press, the right to quit or travel freely in occupied territory. Such suspensions should be made known to the inhabitants.

"288. Nature of laws promulgated.-An occupant may create new laws for the government of a country. He will promulgate such new laws and regulations as military necessity demands. In this class will be included those laws which come into being as a result of military rule; that is, those which establish new crimes and offenses incident to a state of war and are necessary for the control of the country and the protection of the army."

Cf. Article 366 of the English Laws ANd Usages of War ox LAND:

"If demanded by the exigencies of war, it is within the power of the occupant to alter or suspend any of the existing laws, or to promulgate new ones, but important changes can seldom be necessary and should be avoided as far as possible." 
the suspension of existing laws; Rule 288, the promulgation of new laws; and Rule 286, both the suspension of existing and promulgation of new laws. Rule 285 states that, in the suspension of existing laws, it is the principal object of the occupant "to provide for the security of the invading army and to contribute to its support and efficiency and the success of its operations," and provides that "in restoring public order and safety [the occupant] will continue the ordinary civil and criminal laws of the occupied territory which do not conflict with this object."

Whereas Rule 285 deals with the suspension of laws only in so far as the occupant restores public order and safety, Rule 286 deals with the suspension of existing laws of the occupied country in general. As a result, it would seem that in the legislative field of restoring public order and safety, Rule 285 prevails over Rule 286 according to the principle lex specialis derogat legi generali. In fields other than the restoration of public order and safety, however, Rule 286 applies and permits a change of the laws of the occupied country only if such a change is necessitated by "the exigencies of the military service." As far as the promulgation of new laws is concerned, Rule 288 permits such promulgation in cases of "military necessity."

Thus the test used by Rules 285, 286 and 288 narrows the scope of legislation permissible under Article 43 of the Hague Convention. Whereas "necessity" would seem the correct word for permissible changes of the laws under Article 43, Rule 285 speaks of "security of the invading army and its contribution to its support and efficiency and success of its operations," Rule 286 speaks of the "exigencies of the military service," and Rule 288 of "military necessity."

Rule 285 imposes only a duty to continue "ordinary" civil and criminal laws. Hence it seems to imply that laws involving war legislation may be abolished even though the general test for the abolishment of existing laws is not met.43

\section{Applications of Article 43 in Various Fields of Law}

The application of Article 43 of the Hague Regulations might lead to different results in different fields of law. The occupant will be

\section{See also Article 362, which provides:}

"Political laws and constitutional privileges are as a matter of course suspended during occupation: for instance, the laws affecting recruitment and those concerning suffrage, the right of assembly, and the right to bear arms, and the freedom of the press. Special orders, may, however, be necessary to make the suspension of the laws known to the population of the occupied territory, for example, an order forbidding able-bodied men of military age to quit the occupied territory."

43. See Cillekens v. De Haas, Dutch Dist. Ct., Rotterdam, May 14, 1919, cited supra note 20. 
"absolutely prevented from respecting the laws of the occupied country" in the field of public law to a greater extent than in the field of private law since under the Rousseau-Portales doctrine war is supposedly waged against sovereign and armies and not against subjects and civilians. ${ }^{44}$ Thus in the field of constitutional law the occupant is totally independent of the constitution of the occupied country if the maintenance and safety of his military forces and the purpose of war so require. ${ }^{45}$ On the other hand, it has been said that, under the principle of respecting the institutions of the occupied country, "an occupant has no right to transform a liberal into a communist or fascist economy, except so far as military or public-order needs should require individual changes;" ${ }^{46}$ that, therefore, Soriet Russia was not free to transform the Baltic countries into Soviet republics, Germany would not be free to transform the Norwegian economic structure into a totalitarian system of the Nazi type, ${ }^{47}$ and the abolishment of fascism in Sicily and the occupied provinces of Italy constituted a violation of the Hague Regulations. ${ }^{48}$ The Hague Regulations, however, express nowhere the principle that the occupant must blindly respect the institutions of the occupied country. The doctrine first established by Fauchille ${ }^{49}$ would not seem to apply where a political system constitutes a permanent threat to the maintenance and safety of the military forces of the occupant so that there is "absolute necessity" to abolish it.

It is only natural that administrative law is affected to a greater extent by occupation than any other field of law, for administrative laws are usually in conflict with the interest of the occupant. ${ }^{53}$ Accord-

41. See notes 31 and 35 supra.

45. See 2 OPPENHED, op. cit. supra note 7, \$169, pp. 349-50.

46. Fenchenfeld, op. cit. supra note $2, \S 331$, p. $90 ; 4$ BustuanNte, Denecho IRterNaCional Público (1937) § 1067, p. 324.

47. FEILCHENFELD, op. cit. supra note $2, \S 331$, p. 90; see also id. at $\$ 327$, p. $\$ 9$.

48. Davidonis, supra note 9 , at 167 .

49. 2 Fauchille, Tratte de Droit International Punlic (Paris, 1921), \$ 1166(1), p. 228 where it is said: "Comme la situation de l'occupant est eminemment provisoire, il ne doit pas bouleverser les institutions du pays." See also Ferlcaenfeld, op. cil. supra note 2, $\S \S 326-31$, pp. 89-90; Davidonis, supra note 9, at 467 .

Fauchille cites two instances: (1) Division of Belgium into two administrative districts by German decree of March 21, 1917. See also 2 G.ARNER, op. cit. supra note 7, \$ 372, p. 79; 2 Oppenenar, op. cit. supra note 7, \$169, p. 349; 10 Huberich axd Nicol-Spever (exls.), German Legislation for the Occupied Territories of Belgium (Official Texts) (1917) 201-2. de Visscher, La séparation administralize décrété en Belgique par l'autorité allemande (1918) 25 Revue Gentrale de Drott Intern.tion.l Public 92; Feilchenfei.n, op. cil. stppre note $2, \S 329$, p. 89 . (2) Conversion of the University 'of Ghent into a Flemish institution by German decree of Dec. 31, 1915. See also 2 GarNer, op. cil. supra note 7, \$371, pp. 77-8; 2 OpPeneren, op. cit. supra note 7, \$169, p. 350, n. 1; Basdevant, La flamandisation par l'Allemagne de l'Unizersité de Gand (1917) 24 Revue Génúrile de Drolt Iriteriatio:al Public 111; Passelece, La Question Flamlinde et l'Allemagne (1917). See, however, Hatschek, Voelkerrecht als Systeur Rechtlick Bedeuts.luser Stants.ifte (1923) 331.

50. See 2 FAUchille, op. cit. supra note $49, \S 1165(2)$, p. 226; 4 Bustarasite, op. cil. supra note $46, \S 1068$, p. 326. 
ingly, the occupant will immediately suspend the laws concerning (1) press, (2) assembly, (3) bearing arms and ammunition, (4) right of suffrage, (5) right to quit or travel freely, and (6) recruiting in occupied territory. ${ }^{51}$ Thus, when the American Expeditionary Forces moved into the Rhineland in 1918, Memorandum No. 4, the first specific regulation issued by the American Army for observance by the German civil population, ${ }^{52}$ dealt with the sale and bearing of deadly weapons and ammunition, the right of assembly, the sale and use of alcohol, billeting and requisitions. After the occupation was carried out, special orders were issued concerning identification and circulation, ${ }^{b 3}$ delivering and carrying of arms and deadly weapons and ammunition, ${ }^{54}$ sale or gift of alcoholic drinks, ${ }^{55}$ assemblies and meetings, ${ }^{66}$ publications, ${ }^{67}$ post,-telegraph and telephone, ${ }^{58}$ pigeons, ${ }^{59}$ and photographs. ${ }^{60}$ However, it would seem that the occupant cannot suspend customs duties. ${ }^{01}$

The civil officials of the occupied country are not bound to continue in service. ${ }^{62}$ On the other hand, if they do so continue, the occupant is not bound to retain them. ${ }^{63}$ Undoubtedly the occupant cannot require an oath of allegiance from them, since they remain citizens of the occupied country ${ }^{64}$ but he can require an oath of obedience. ${ }^{65}$ Although

51. See 2 HYDE, op. cit. supra note $8, \S 690$, p. $367 ; 2$ FAUCHILLE, op. cil. sulfra note 49, $\S 1165(2)$, p. 226.

52. American Military Government of Occupied Germany: 1918-1920, Report of the Officer in Charge of Civil Affairs (1943) 32-40.

53. Id. at 105-7.

54. Id. at $107-10$.

55. Id. at 110-3.

56. Id. at $113-5$.

57. Id. at $115-6$.

58. Id. at 116-7.

59. Id. at $117-8$.

60. Id. at 118.

61. See 2 Fauchille, op. cit. supra note $49, \S 1165(2)$, p. 227. A German decree of Jan. 3, 1915 provided that the Belgian custom laws should apply to the French territorics of Givet-Fumey which were controlled by the German Governor-General established in Belgium.

62. Colby, Occupation under the Lawes of War (1926) 26 CoL. I. REv. 146, 152; BukK. himer, Military Governaent and Martial Law (3d ed. 1914) 68.

63. 2OppenheIM, op. cit. supra note 7, pp. 349-50; Colby, supra note 62, at 152-3. Sce also U.S. WAR DEP'T, op. cil. supra note 41 , Rule 311.

64. 2 FaUchille, op. cit. sulpra note $49, \S 1174$, p. 240; StrupP, op. cil. supra note 19, at 102. See also U. S. WAR DEP'T, op. cit. supra note 41, Rule 298.

65. SPAight, War Rigets on LAND (1911) 366; 2 MeURER, op. cil. supra note 12, at 241; STRUPP, op. cit. supra note 19, at 102. See also U. S. WAR Dep'T, op. cil. silpra note 41, Rule 309. But see the French Manuel A l'Usage Des Officiers; (1898) 5 Revur Gen. ERAle de Drojt International Public 803.

The Germans in their Belgian occupation of 1914-1918 required the retained Belgian officials to make the following declaration of loyalty: "I hereby promise to continue to administer my office conscientiously and loyally, in accordance with the Hague Convention of October 18,1907, and not to perform or omit any acts which would be harmful to the German administration in the occupied Belgian territories." 
civil officials remain subject to the disciplinary laws of the occupied country in the event they violate their duties, it would seem that a violation which is harmful or injurious to the occupant may also be dealt with under the laws of war. ${ }^{\text {ci }}$

It is the general rule that the organization of the courts of the occupied country should remain intact. ${ }^{67}$ However, special tribunals may be established in the following instances: (1) to deal with offenses by citizens of the occupied territory against the authority of the occupying forces or against persons belonging to the armed forces of the occupant or in violation of regulations issued by the occupant; ${ }^{\mathrm{cs}}(2)$ to replace the regular courts if the local administration of justice is completely disorganized; ${ }^{69}$ and (3) to deal with members of the military forces of the occupant. ${ }^{70}$ If the political system of the occupied country con-

66. See U.S. WAR DEP'T, op. cit. supra note 41, Rule 312:

"Punishment of ciril afficials. - Acts of civil officers that are harmful or injurious to the occupant will be dealt with under the laws of war. Other wrongs or crimes committed by them will be punished according to the law of the land."

67. 2 FACCHחLE, op. cit. supra note $49, \S 1168$, p. 232.

In Belgium by German ordinance of Feb. 3,1915 , provision was made for the creation of special tribunals in each province to determine the amount of damage for which municipalities were held responsible in case of violence, theft, and outbreal: on the part of the inhabitants.

By another German decree of Feb. 10, 1915, provision was made for the creation of a new set of special tribunals to decide disputes between landlords and tenants.

As to the recognition of these courts, see 2 G.LRNER, op. cil. supra note 7, $§ 374$, p. 83; 2 HUBERICH AND NiCOL-SPEYER, op. cit. sapra note 49, at 57-9; (1917) 44 Joursial DU DROIT INTERNATIONAL (Clunet) 1003; (1915) 42 id. at $28 s$.

On the practice of the Italians occupying Austrian territory see Gesus, Appestr DI DiRITTO INTERNAZIONALE (1923) 355.

68. 2 GARNER, op. cit. supra note 7, 375 , p. $85 ; 2$ FatcunLE, op. cil. sufra note 49, $\$ 1170$, p. 237; BirkHISER, op. cit. supra note 62, at 38, 47; 1 WINTRHop, Millitary LaW (1886) 961; 4 BUSTAMrENTE, op. cit. supra note $46, \S 1070$, pp. 338-9.

In practice, military occupants have usually acted in accordance with this theory.

During the war between the United States and Mexico (1846-1848), General Scott organized special tribunals called "Military Commissions." Similar tribunals were organized by the federal authorities in the Southern States during the Civil War. During World War I, provost courts, military commissions, and a court for vagrants and juveniles were established in the Rhineland.

69. Such special courts were organized (a) by Lord Roberts in Transwaal in 1900; (b) by France in the German colony of Cameroon in 1916 and 1917 (decrees of May 6, 1916, and Jan. 12, 1917); (c) by France in Alsace-Lorraine in 1914, when the German judges had fled; and (d) by Germany in Belgium in 1914 after the so-called "judges' strike." See 2 GARNER, op. cil. supra note $7, \S 378$, p. $91 ; 2$ Fauchille, op. cil. supro note $49, \S 1169$, p. 232; 2 OPPENHED, op. cit. supra note $7, \S 172$, p. 387, n. 2 ; Colby, stpre note 62 , at 159 ; GlenN, The ARMY aNd IHe LAW (1918) 90-7; 4 Bustasunte, op. cil. sufra note 40, $\S 1071$, p. 340 .

70. 7 Moore, Digest of International Law (1906) 257 el seq.; Valert, Droit International Prive (1914) 101; 2 v. Bar, Lehrbecr des Internationales Privat-

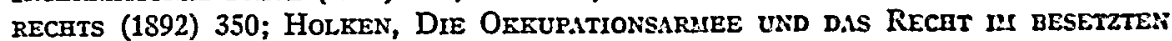
Gebiet (1917) 31, 42; Contra: Frisch, Der Voelierrechtliche Begriff der ExterRITORIALITAET (1917) 47. 
stitutes a threat to the security of the occupant's army, it seems that as a matter of military necessity the occupant is entitled to destroy those courts which are closely connected with that system. Thus there is little doubt that the Allies should be entitled under Section 43 to abolish the German People's Court, an institution designed to impose severe penalties upon those who committed major political crimes. In addition, they are authorized to deprive German courts of the jurisdiction to deal with minor political crimes given to them by the Nazi Government.

While the occupant has a right to remove judges, ${ }^{71}$ those judges who remain have the right not to be interfered with by. the occupant in passing judgments, ${ }^{72}$ and they cannot be compelled to pronounce judgments in the name of the occupant. ${ }^{73}$ On the other hand, the occupant need not allow them to render their verdicts in the name of the legitimate government. ${ }^{74}$.

It is an established general principle that the local civil and criminal law should be respected by the occupant. ${ }^{75}$ However, necessity created either by the occupied country's interest in the restoration of public order and civil life or by the occupant's military interest may justify a great number of changes. ${ }^{76}$ During the occupation of the Rhineland at the end of the first World War, the proclamation of Marshal Foch as Commander-in-Chief of the Allied forces declared that the "laws and regulations in force at the moment of occupation will be continued in so far as they do not affect our rights or our safety." 77 At the same time General John J. Pershing, as Commander-in-Chief of the American

71. 2 GARNER, op. cit. supra note $7, \S 373$, p. $81 ; 2$ OPPENHEIM, op. cil. supra note 7, $\S 172$, p. 349 .

As to the removal of Jewish judges by the Russians during their occupation of Lemberg in the World War, see Cybichowski, Die Beselzung Lembergs im Kriege 1914-15 (1916) 26 ZEITSCHRIFT FUER INTERNATIONALES RECHT (Niemeyers) $427,452$.

72. 2 OPPENHEIM, op. cit. supra note $7, \S 172$, p. $349 ; 4$ Bustamante, op. cit. silpra note $46, \S 1071$, p. 341.

73. 2 OPPENHEIM, op. cit. supra note $7, \S 172$, p. $349 ; 2$ FAUCHILLE, op. cil. supra note 49 , $\S 1169$, p. 232. See also Stauffenberg, supra note 7 , at 104; 2 GUELLE, PrECIS DES Lors DE LA Guerre (1884) 18; 7 Pradier-Fodere, Traite de Droit InTERnational Pudlic (1897) 821; 1 Merignhac and LEMonon, Le Droit des Gens et la GUerRe de 1914-1918 (1921) $355 ; 4$ BustaMaNTE, op. cit. supra note $46, \S 1071$, p. 341.

74. 2 OpPenheis, op. cit. supra note 7, $\$ 172$, p. 349; Cybichowski, supra note 71, at 448; WUNderlich, Der Belgische Justizstreik (1930) 49.

75. 2 GARNER, op. cit. supra note 7 , at $85 ; 2$ FAUCHILLE, op. cit. supra note $49, \S 1166$, pp. 227-8. 4 BUSTAMAANTE, op. cit. supra note $46, \S 1069$, p. 336.

76. At the conference of Brussels, session of Aug. 12, 1874, Colonel Count Lanza voiced the opinion that civil and penal laws which have not a political character would remain in force under the draft of Article 3 of the Declaration of Brussels. Acres DE LA CONFERENCE DE BruXelles DE 1874 (Brussels, 1899), 135-6; 4 Martens, Nouvenu RecueIL GENERAL DE Traites (2d ser.) (1879) 77.

77. American Military Government of Occupied Gersany, op. cil. supra note 52, at 30 . 
Expeditionary Forces, declared in his proclamation to the inhabitants of the area occupied by the American Forces that "the existing laws and regulations, in so far as they do not interfere with the duty and the security of the American troops, shall remain in force." is

During the occupation of Belgium in 1914-1918, Germany promulgated a large number of new laws affecting trade, education, health, language, business, and ordinary industrial pursuits such as agriculture, stock-breeding, slaughtering of livestock for food, muzzling of dogs, feeding of animals, planting and harresting of crops, the sale of produce, the tanning of hides, and the conservation of foods. ${ }^{73}$. Whether all these regulations were justified by necessity, either in the interest of the population or in the military interest of Germany, has been doubted. ${ }^{80}$

In this war it would seem that Article 43 permits the Allies to change the civil and criminal laws in those instances in which the change is justified by necessity either in the interest of the population or in the military interest of the Allies. Since the Nazi system constitutes a threat to the security of the occupant's army, the occupant will consider it an absolute necessity to change all civil and criminal laws and provisions which reflect Nazi ideology. Thus it would seem that all civil and criminal laws and provisions could be abolished which express racial, religious, or political discrimination. ${ }^{81}$ In addition, non-discriminatory laws emanating from racial fanaticism could be abrogated under the rule of necessity. ${ }^{82}$ A more complicated question

78. Id. at 31-2.

79. 2 G.ARNER, op. cit. suspra note $7, \S 376$, p. 88 .

80. Ioid.

81. See, e.g., "Law for the Protection of German Blood and German Honor" (Gesc/s zum Schutz des dentschen Blutes und der deutschen Ehre) of Sept. 15, 1935, REICrsGesEIzBLATT (hereinafter cited as RGBI.) 1. 1334; "Law concerning Restrictions of Testamentary and Intestacy Rights of Persons on account of Their Conduct against the Common Interest" (Gesetz ueber erbrechtliche Beschraenkungen aegen gemeitzschafts ardrigen Verhaltens) of Nov. 5, 1937 (RGB1. 1. 1161); "Law concerning Change of First Names and Surnames" (Gesele ueber die Aenderung ron Familiennamen und Vornamen) of Jan. 5, 1938 (RGBI. 1.9), "Sacond Supplementary Decree" of Aug. 17, 1938 (RGBI. 1. 1044), "Third Supplementary Decree" of Dec. 14, 1940 (RGBl. 1. 1669); "Law concerning Lease Agreements with Jews" (Gesels useber Misetszerhaeltnisse mit Juden) of April 30, 1939 (RGBI. 1. S64).

There are also a number of statutes which contain one or several provisions designed to discriminate in political, racial, or religious respect. See, e.g., Sections 4,20 , and $2 \delta$ (1) of the "Law on Marriage and Divorce" of July 6, 1938 (RGBI. 1. 807); various provicions of the "Law concerning the Status of Persons" of Nov. 3, 1937 (RGBI. 1. 1146); Szetion 4 of the "Eleventh Executory Decree Concerning Reich Citizenship" of Nov. 26, 1941 (RGBI. 1. 722).

82. "Iaw for the Prevention of Hereditarily Diseased Offspring," July 14, 1933 (RGBI. 1. 529); Section 1 (d) of the "Law for the Protection of the Hereditary Health of the German People" of Oct. 18, 1935 (RGBI. 1. 1246). 
arises where a general clause ${ }^{83}$ has been used by German courts to implement Nazi principles. Since previous interpretations of these clauses by the courts do not constitute as strong precedents as they would in Anglo-American law, no legislative action would seem necessary.

Nazi war legislation has actually disrupted the German administration of justice. Thus in the field of substantive law business contracts are no longer binding; the judges are authorized, in effect, to extend the time of performance, to order instalment of payments, to modify a contract in every other way and even to cancel it. ${ }^{84}$ In the field of civil procedure cases are retained on the docket only when the trial cannot possibly be postponed, ${ }^{85}$ and the right to appeal has been virtually abolished. Since these and other war laws do not enjoy the protection of Article 43 they could be modified or abrogated at any time. Whether this is a wise policy during the initial stage ${ }^{86}$ of occupation is a different question.

\section{Cases in Which Article 43 Is Inapplicable}

Delegation of Power. Does the limitation of the legislative power of the occupant imposed by Article 43 lose its force where the statutes of the occupied country provide for broad delegation of power to administrative officials? It could very well be argued that, since the legislative body of the occupied country has expressly consented to the abrogation and abolishment of law by delegation of power, the law "of the occupied country is respected" even though it is changed by the occupant. This conclusion would be a matter of necessity at least in those instances in which administrative agencies of the occupied country have always exercised quasi-legislative functions which, after occupation, might be carried out by members of the military government.

83. See Sections $133,138,157,242$, and 826 of the German Civil Code; see also Section 48 (2) of the "Law Concerning the Making of Wills and Agreements of Inheritance" of July 31, 1938 (RGB1. 1. 973) and Sections 12-21 of the "Act Amending the Law of Family Relations," April 12, 1938 (RGBI. 1. 380).

As to cases interpreting the aforementioned sections in the "Nazi spirit," see Adami, Das Program der N.S.D.A.P. und die Rechisprechning (1939) 9 Deurscues Recur (A) 498. See also Jenne, Volksverbundene Rechisprechang (1936) 1 Deutscue RecutsprLEgE (1936) 166; Dickman, Outline of Nazi Civil Law (1943) 15 Miss. L. J. 127-34; Note, The Place of Law in Germany (1943) 59 L. Q. REv. 140.

84. See decree of Nov. 30, 1939, Verordnung ueber Veriragshilfe des Richtcrs aus Anlass des Krieges (RGBl. 1. 2329); see also decrees of April 20, 1940 (RGBl. 1. 671) and Dec. 11, 1942 (RGBl. 1. 706).

85. Decree concerning war measures in the field of civil procedure of May 12, 1943 (RGBl. 1. 290). See also decree concerning the saving of personnel in criminal matters, May 29, 1943 (RGBl. 1.346).

86. See Zweite Kriegsmassnalmenverordnuntg of Sept. 27, 1944 (RGB1. 1. 229). As a result, all courts of appeal (Oberlandesgerichte) including the Kammergericht have been eliminated. 
Waiver. Whether the limitation contained in Article 43 can be waived by the sovereign of the occupied country is part of the broader issue of whether the provisions of the Hague Convention on land warfare can be altered by an agreement of the belligerent parties. It might be coritended that, since the provisions of the Hague Convention are terms of an agreement, they can be changed by the parties. ${ }^{g 7} \mathrm{How}-$ ever, aside from the possibility that all parties to the Hague Convention must consent to its modification, these provisions might be considered merely a restatement of unwritten law. Hence, the final answer must depend on whether the provisions of the Hague Convention are to be considered ius dispositivum or inls cogens. That they constitute ius dispositivum has been most ardently urged by Strupp in discussing the validity of the German-Allied armistice of November 11, 1918:

"If . . . numerous so-called violations of the law of nations in this war have never been committed either for lack of factual evidence or in the absence of pertinent law, it is extremely regrettable that even lawyers have attempted to consider the armistice provisions as being inconsistent with the law of nations. For they have overlooked the fact mentioned in connection with another subject matter that, assuming an inconsistency between the armistice provisions and either the written or customary law of nations, each of its principles may be altered by agreement due to the derogatory nature of the law of nations. And as the doctrine 'dura lex, sed lex' is an established principle of domestic law, the corresponding principle of 'dura conventio, sed conventio' must be also true in the field of the law of nations." 89

But Strupp's premise is rather doubtful, since a "dura conventio" may very well be invalid if it violates a principle of the law of contracts which cannot be waived, such as "public policy" or the "statute of frauds." It is submitted that no general doctrine can be laid down and that those principles of the law of nations which constitute the minimum requirement for civilized warfare cannot be waived, whereas others may be. Under this theory, the principle embodied in Article 43 would seem to be subject to abrogation.

In practice, Article 43 has been waived. Thus, by virtue of Articles 3

87. Fenc CHENFELD, op. cit. supra note $2, \S 407$, p. 114, takes the position that modern international law does not restrict the validity of armistice stipulations which provide for harsher treatment than that permitted under the Hague Regulations. He says: "There is no evidence in State practice that such restrictive rules have become a part of international law." See also Davidonis, supra note 9, at 467.

The term "unconditional surrender" as used in the Declaration of Mloscow, Oct. 30, 1943 , means complete surrender of all armed forces and the opening of all the enemy's territory to military occupation.

S8. Strupp, Das Wafferstillstandsabkommen rom 11. Norember 1918 (1919) ZErTschrurT FUER VOELKERRECHT 252, 257; see also HeYL.AND, DIE RECHTSSTELLU:io DER DESETZTE: RaEINLANDE (1923) 66-9; FEILCBENFELD, op. cit. supra note 2, $\$ 407$, p. 114. 
and 5 of the Rhineland Convention of 1919, the inter-Allied high command issued a regulation requiring the registration of German statutes and regulations which were in effect prior to the occupation as a prerequisite of their validity in the Rhineland. While the German courts declared this regulation invalid, they did so, not because it violated Article 43, but because, under their construction, Articles 3 and 5 of the Rhineland Convention did not authorize the inter-Allied high command to issue such a regulation. ${ }^{89}$

Unconstitutional Laws. Article 43 would also seem inapplicable if the laws of the occupied country are invalid under its own constitution as it existed at the time they were enacted. When the invalidity of laws has been determined within the occupied country, this principle governs beyond peradventure. Where, however, invalidity has not been so established, the question arises, whether the occupant may pass judgment on constitutionality. In those occupied countries in which domestic courts or special agencies are authorized to invalidate laws, the occupant must respect this practice as part of the domestic laws of the occupied country in accordance with Article 43. But if no such special procedure is provided for the invalidation of laws, there seems to be no reason why the occupant should not pass on their validity. ${ }^{90}$

89. See Reichsfinanzhof (German Tax Court), Dec. 7, 1926 [1926] 2 Dic Rechtsprechung des Reichsfinanzhofs in Leitsaetzen 68, reprinted in (1927) 56 JURISTISCuE WocuENSCHRIFT 2330. Reichsgericht (German Supreme Court), Sept. 22, 1922, 105 Entscheidungen des Reichsgerichts in Zivilsachen 179, 181, and March 7, 1922, 56 Entscheidungen des Reichsgerichts in Strafsachen 288, 289.

90. American courts have in general declined to review the validity of acts carried out by public officers of foreign countries.

In regard to civil officials of foreign countries, see Earn Line S.S. Co. v. Sutherland S.S. Co., 254 Fed. 126, 129 (S. D. N. Y. 1918), aff'd sub nom. The Claveresk, 264 Fed. 276 (C. C. A. 2d, 1920); Hewitt v. Speyer, 250 Fed. 367 (C. C. A. 2d, 1918); Banco de Espana v. Federal Reserve Bank; 114 F. (2d) 438, 443 (C. C. A. 2d, 1940); cf. The Navemar, 102 F. (2d) 444 (C. C. A. 2d, 1939).

In regard to military officials of foreign countries, see Union Shipping \& Trading Co. v. United States, 127 F. (2d) 771, 774 (C. C. A. 2d, 1942); Underhill v. Hernandez, 168 U. S. 250 (1897); Oetjen v. Central Leather Co., 246 U. S. 297 (1918); Ricaud v. American Metal Co., 246 U. S. 304 (1918). Contra: Government of Kingdom of Belgium v. The Lubrafol, 43 F. Supp. 403 (E. D. Tex. 1941); Fields v. Predionica I Tkanica A. D., 35 N. Y. S. (2d) 408 (Sup. Ct. 1942).

However, in regard to the validity of foreign statutes under foreign constitutional law, the position of the courts seems to be different. Thus, in Canada Southern Ry. v. Gebhard, 109 U. S. 527 (1883), the Supreme Court of the United States reviewed the constitutionality of a Canadian act under Canadian constitutional law. See also Sabariego v، Maverick, 124 U. S. 261 (1888) and Shapleigh v. Mier, 299 U. S. 468 (1937), where the Supreme Court passed on the validity of Mexican acts under Mexican law.

In the field of conflict of laws it also seems that courts may review the constitutionality of a foreign statute under the respective foreign constitutional law, if the domestic courts of the foreign country are permitted to do so. Ct. of App., Paris, June 13, 1928, and Ct. of App., Bordeaux, Jan. 2, 1928, [1928] RecuEiL GENerale DEs LoIS ET DEs ArRêts (Sircy) 2. 161; see also decision of a lower Austrian court reported in (1941) 50 YALE L. J. 1031. 
Ultra Vires Legislation and Extraterritorial EFfect

Many courts have assumed the right to examine whether the occupant's measures comply with Article $43 .{ }^{91}$ The wisdom of these deci-

Nussbaum, Principles of Private Internationil L.1W (1943) 258; Niboyet, Ou'esl-re que la loi éfrangère aux yetux des juges d'un pay's déterminé (1928) 9 REVUE DE DROrt INTTERNational (3d series) 753, 76t-72; Nussbaum, Problem of Proing Forcign Lavo (1941) 50 YALE L. J. 1031; Note, Protectize Expropriatory Decrees of Goxemments in Exile (1941) 41 CoL. L. Rev. 1072.

91. Revieving the question whether the occupant's legislative action complied with Article 43, Hague Regulations, these legislative acts were held to be valid in the following cases:

Cillekens v. De Haas, Dutch Dist. Ct., Rotterdam, May 14, 1919, discussed stupran, p. 000 , where the decision of the court was based on the theory that Article 43 applies only to ordinary laws, but not to war measures. In addition, the court said: "Even if that were othervise, it would in any case be in the interest of public order and safety to restrict the moratorium to the shortest possible term. At the moment of the repsal of the moratorium it was impossible to foresee the end of the occupation of the larger part of Belgium, so that it might have been desirable not to wait till the end of the war to terminate the moratorium. Consequently, this measure may be considered to have served the re-establishment and insurance of public order and safety in Belgium, and be considered as lawful." Winumus AND LAUTERPACHT, op. cit. supra note 3, at 471 . See to the same effect, Oesterrieth \& Co. v. Emile Dierck, Dist. Ct., Breda, May 22, 1917, [1917] Nederlasidscne Junisnudde:itic 594, (1917) 2 Int. L. Notes 127; Elias v. Bak, Dist. Ct., Haarlem, Oct. 9, 1917, [1917] NEDerLANDSCHE JURISPRUDENTIE 1079.

In Bochart v. Committee of Supplies of Corneus, Belgian Ct. of App., Libe, Feb. 28, 1920, Willians and LAUTERPacer, op. cit. sapra note 3, No. 327, p. 462, an order of Aug. 8 , 1918 of the German Governor-General in Belgium declared void all purchases of vesetables not yet gathered. The appellant sued for the specific performance of such a contract, asserting the illegality of the German order for the reason that it sought to benefit the occupant rather than the occupied country. The order was held to be valid. The court said: "In fact, the occupying Power, even if it may have contemplated the possibility of a personal profit for its own nationals, nevertheless took its action with a view to regulating and diminishing the exorbitant price of vegetables. It acted in the place of the legitimate authority which for the time being had been ousted, and in conformity with the provisions of Article 43 of the Hague Convention." Ibid.

In City of Malines v. Société Centrale pour l'Exploitation du Gaz, Belgian Ct. of App.,

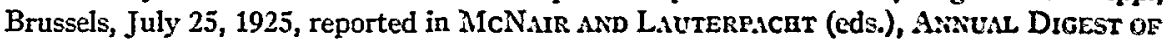
Public International Law Cases: 1925-1926 (1929), No. 362, p. 475, an appeal was brought against the decision in favor of a company which claimed certain sums from the City of Malines corresponding to the increase of the cost of supplying gas, the increase being due partly to the measures taken during the war by the occupying authorities. The City maintained against the claim that the decrees of the occupying authority were invalid. The Court of Appeals affirmed, saying that "the circumstances of war-time, and particularly the increase in the cost of raw materials and the necessity for providing for the needs of the population, in fact justified the measures taken by the occupying authorities; that on this ground these measures come within the scope of the administrative acts permitted to the occupying Power by the Hague Convention No. IV (Article 43 of Anneved Regulations) with a view to the maintenance or reestablishment of order and Eafety; and that consequently the decree in question must be regarded as applicable." Ilid.

See also similar decisions by Court of Appeals of Liège, June 4, 1919, [1919] 2 Pasicrusie BELGE 137; June 25, 1919, [1920] 2 id. at 208; Feb. 21, 1920, [1920] 2 id. at 112.

The legislative acts of the occupant have been held to be invalid in the following cases: 
sions is doubtful. While such a review would constitute a convenient check on ultra vires legislation, it seems questionable whether the Hague Convention intended to sanction reviewability of the measures taken by the military occupant..$^{92}$ It is difficult to assume that ordinary judges, and sometimes justices of the peace or their substitutes, are in a position to determine whether a law was necessary or not. ${ }^{03}$ It is there-

Ville d'Anvers v. Etat allemand, German-Belgian Mixed Artibral Tribunal, Oct. 19, 1925, (1925) 5 Recueil des Decisions des Tribunaux Arbitraux Mixtes 712, 6 HaCkWORTH, op. cit. supra, at 395-6. The City of Antwerp made claim against the German Government for the amount of sentences pronounced against it by an arbitral tribunal established by a German decree of February 3,1915, and modifying a former Belgian decrce of the "Ten Vendémiaire, Year IV." The German-Belgian Mixed Arbitral Tribunal recognized the responsibility of the German Government to compensate the City of Antwerp in respect to these sentences. It said: "Article 43 provides that 'the authority of the legitimate power having in fact passed into the hands of the occupant, the latter shall take all the measures in his power to restore and ensure, as far as possible, public order and safety, while respecting, unless absolutely prevented, the laws in force in the country.' The respect for the Bejgian laws was therefore for the occupant a duty which ceased only in case of being 'absolutely prevented.' It is quite obvious that there was no military motive which could have justified the abrogation of said decree, i.e., the deprivation of the Belgian tribunals, of its jurisdiction, and the creation of arbitral tribunals. Even if one would construe Article 43 to the effect that the occupant may modify the existing laws whenever it appears necessary for the maintenance of public order, maintenance of public order did not require the creation of such an exceptional jurisdiction. The Belgian tribunals which had jurisdiction functioned normally ...." (Translation by author.)

In re X, French Ct. of App., Nancy, Jan. 8, 1920, (1920) 47 Journal du Drort INTERNatronal (Clunet) 213; Whlliams and Lauterpacht, op. cit. sulpra note 3, No. 334, p. 468; 6 HAckwitB, op. cit. supra note 3, at 397. The judges of the court of first instances of Bricy and Congry remained at their posts at the beginning of the German Occupation. The German authorities subsequently relieved them of their functions and replaced them by a court established in the name of the German Empire on June 14, 1917. A woman charged with infanticide was acquitted by a decision of this court. When she was prosecuted ancw for the same facts by a French court she pleaded double jeopardy. It was held that the defense of double jeopardy did not lie: "The decision . . . of the Court created by the German authority could not produce any effect, direct or indirect, in France. . . . Articlo 43 of the Hague Convention in no way authorized the occupying authorities to stuppress in the occupied regions French courts which, so far from disturbing public order, safegutarded it. Moreover, the crime of infanticide is not among those reserved in principle by the law of war to the cognizance of the enemy as being likely to jeopardise the security of his army." WILlIAMSS AND LAUTERPACHT, supra, at 469.

In De Brabant and Gosselin v. T. and A. Florent, Belgian Ct. of App., Brussels, July 22. 1920, WLLIAMS AND LAUTERPACHT, supra, No. 328, p. 463, the facts were the same as in the case of Bochart v. Commiltee of Supplies of Corneux, sutpra. However, the court held the German order invalid: ". . . the German Order . . . was not made with a view to assuring public order and security, but to starving the population. It went beyond the powers given to the occupant by Article 43 of the Hague Convention; it never had the force of law and cannot therefore avoid an agreement properly concluded by the parties." Ibid.

92. See Meurer, op. cit. supra note 4, at 22: "Of course, as stated by v، Martens at theHague Convention, the occupant himself is entitled to determine whether a case of necessity exists, and his determination is not subject to review." (Translation by author.)

93. See Leurquin, supra note 25 , at 56: "It is certain that the check upon such legislation presented by the judiciary of a country such as Belgium would constitute a guaranty for 
fore not astonishing that the Belgian and German Supreme Courts have denied the power of the courts to review measures of the occupant under Article $43 .{ }^{94}$

the people, and this guaranty, if it results from the intention of the contracting States themselves, should be loyally respected by the occupant. It appears very doubtful, however, whether the Hague Convention meant to sanction this. It is difficult to assume that ordinary judges and sometimes justices of the peace or their substitutes are in a position to decide whether a law was necessary."

94. See 2 GARNER, op. cit. supra note 7, at SS, n. 1, referring to 2 WestrakE, ItiterNatjonal Latw (2d ed. 1913) 97. Cf. Feilchienfer.d, op. cil. stupra note 2, $\$$ 493-9. p. 143.

In a decision of the Court of Cassation of Belgium, May 18, 1916, (1916) 1 Irit. L. Notes 136, 138 the court refused to review whether a German decree complied with the limitations expressed in Article 43 ,

". . . which it is true, imposes upon the occupant the strict obligation of tal:ing the aforesaid measures, also prescribes the various methods which the occupant is to observe in carrying out his task: (1) he is to do that which rests sith him; (2) he is to act in so far as possible; (3) he must have respect, on taling these measures, for the laws of the country and shall not depart therefrom unless it be absolutely necessary;

"But whereas the difficulties with regard to the alleged non-compliance with some of the aforesaid methods and the manner in which the occupant has discharged his duty merely concern international relations, and their solution can only lead to the application of the sanction as set out by Article 3 of the Convention;

"That if they attempted to solve these difficulties, the judicial authorities of the occupied territory would encroach upon the prerogative of the competent national power, that they must therefore abstain from doing so under pain of acting ultra sires."

A German decision of the German Supreme Court, rendered Oct. 24, 1920, and reported in Bruns, Fontes JURIS GeNTIUM, Ser. A, \$2, vol. 1 (1931) No. 205, p. 575, involves the question whether the accused had violated a German war decree of April 18, 1917, prohibiting the export of silver in the Rhineland, where the decree has been suspended by the Inter-Allied Commission. The German Supreme Court held that the suspension of the decree by the Allied commission was valid: "At the time of occupying German territory", the Allies assumed exercise of the entire government in it. Government also includes legislative power. According to Article 43, Hague Regulations of October 18, 1907 (RGBl. 1910, p. 147), the military authorities, - that is, according to Article 3 of the agreement concerning occupation of the Rhineland of June 2S, 1919 (RGBI. 1919, p. 1339), the High Inter-Allied Commission - had jurisdiction to exercise the legislative power. The aforementioned provisions also defines the scope of legislative power. If the limits laid down by them should be transgressed, there would be a breach of an international agreement. The legal consequences of such a breach must be determined by the law of nations. The courts of the occupied territory are not in a position to determine whether the Allies in esercising legislative power in the occupied territory exceeded their power; for instance, whether a cogent obstacle (emp schement absolu) existed within the meaning of Article 43, which prevented them from respseting the laws of the occupied country." (Translation by author.)

See also decision of the German Supreme Court of June 7, 1921, 102 Entscheidungen des Reichsgerichts in Zivilsachen 255, 256, where the question was left open.

On the other hand, the German Reichs Tax Court (Reichefinanzhof) as well as the German Supreme Court have held that, where an international agreement such as that concerning the occupation of the Rhineland of June 28,1919 , has been transformed into municipal law by passing it as an act of the legislative body, the municipal courts of the occupied 
Most courts refuse to give extraterritorial effect to measures taken by the military occupant. ${ }^{95}$ Whether such refusals constitute valid precedents governing extraterritorial effect of legislative measures seems doubtful since the cases in which they were made involved administrative acts, such as the sequestration of property, rather than legislation. In so far as purely legislative measures have been tested in controversies before courts of neutral countries, they have been recognized. Foreign exchange regulations issued by the German occupant in Czechoslovakia, Austria and Holland have been recognized in other countries, ${ }^{96}$ and in Cillekens v. De Haas ${ }^{97}$ a legislative measure of a military occupant extending a moratorium was recognized by a court of a neutral country. As a result it would seem that legislative measures of the occupant should be given extraterritorial effect. A fuller answer on this, as well as on other problems in the field, must await further developments on the European continent.

country are permitted to review the scope of authority which the agreement confers upon the occupant or his agencies (so-called theory of transformation). See cases cited supra note 89. See also Vogels, Das Raeinlandabkommen (1920) 44; Luettger, Das Pruefutgsrecht des deutschen Richters gegenueber den Verordnungen der Rheinlandkommission (1924) 53 JURISTISChE WocheNschrift 1349; Luettgen, Zum Recht des beselzen Geticts (1925) 54 id. at 19; Klafisch, Die Gesetzgebung im besetzten Gebiet (1924) 53 id. at 1687; Neubert, Dio Gesetzgebung im besetzten Gebiete (1925) 54 id. at 458; Schaetzel, Der Friedensverirag als Reichsgesetz (1920) 25 Deutsche JuRISTENZEITUNG 196.

95. Extraterritorial effect has been. denied in Société de Sosnowice v. Banque de Dépôts et de Crédit, Swiss Trib. 1st inst., Geneva, Oct. 30, 1917, (1918) 14 Revue dre Dro1t International Prive 190; Comptoir d'Escompte v. S. A. Charbonnages Sosnowice, Swiss. Trib. Fédéral (Sup. Ct.), Nov. 22, 1920, (1921) 43 LA Semaine Judicinire 81; S. Papadoulos of Péra (Constantinople) v. (1) N. V. Koninklijke Nederlandsche Stoombootmaatschnppij of Amsterdam, (2) J. W. Whittall \& Co., Ltd., of Constantinople, Dutch Dist. Ct., Amsterdam, April 17, 1925, McNaIr and LaUTERPACBT, op. cil. supra note 91, No. 19, p. 27; Russian Trade Delegation v. Société Française Industrielle et Commerciale des Pétroles (Groupe Malopolska), French Trib. Civ., Seine, Jan. 12, 1940, (1940) 17 Recueil HebdomadaiRE DE JuRisprudence (Dalloz) 68, LaUter pacht (ed.), ANnual Digest and Rerorts of Punlic International Law Cases: 1938-1940 (1942) No. 83, p. 245. Amstelbank, N. V. v. Guaranty Trust Co. of New York, 177 Misc. 548, 552, 31 N. Y. S. (2d) 194, 199 (1st Dep't 1941); Koninklijke Lederfabriek "Oisterwijk" N. V. v. Chase Nat. Bank of City of New York, 30 N. Y. S. (2d) 518 (Sup. Ct. 1941). Cf. Bank of Ethiopia v. National Bank of Egypt and Ligouri, [1937] 1 Ch. 513, where an Italian occupation measure in Ethiopia was recognized.

On the effect of occupation measures other than legislative acts, sce Niboyet, De l'effet en pays neutre des mesures de guerre (1920) 16 Revue DE Drort INTERNationaL PRIVE ET DE Drort Penal Internatronal 248; Wright, The British Coutrts and Ethiopian Recogntilion (1937) 31 As. J. INT. L. 683.

96. They were recognized in Anglo-Czechoslovsk Bank v. Janssen (1944) 17 AUst. L. J. 330; Werfel v. Zivnostenska Banka, 287 N. Y. 91 (1941), 23 N. Y. S. (2d) 1001 (1st Dep't 1940); Johnson v. Briggs, 12 N. Y. S. (2d) 60 (N. Y. City Ct. 1939). Extraterritorial effect was denied in Sabl v. Laenderbank Wien Aktiengesellschaft, 30 N. Y. S. (2d) 608 (Sup. Ct. 1941).

97. Cillekens v. DeHaas, Dutch Dist. Ct., Rotterdam, May 14, 1919, citcd supres note 20. 


\section{CoNCLUSION}

Even though the legislative power of the military occupant is theoretically limited, practically it includes jurisdiction over the entire civilian life of the enemy population if the occupation extends over a considerable period of time. As a result, in the present war situation AMG (the American Military Government) is faced not only with the task of supervising the administration and judiciary of the enemy country, but also with the job of abolishing existing and enacting new laws and decrees. The denazification of the German legal system will have priority. In addition AMG will have to establish an appropriate machinery for the distribution of food and the allocation of raw materials, because food and raw materials will be scarce. Their efficient distribution is necessary for the restoration of public order and civilian life, and such a restoration seems in turn a condictio szme qua non for the accomplishment of allied war aims. This task of distribution will be all the more difficult, since there will be no central government to deal with, as in 1918. Thus ANIG will be confronted with the problem of whether to use the existing control agencies ${ }^{\text {ss }}$ or to establish new

98. Under the present German economic control system two kinds of control agencies have been established, one under the Minister of Economic Affairs (Rciclsurirlschoftsminister) and another under the Minister of Armament and War Production (aririster futer Ruestung und Kriegsproduktion). Even before the outbreal: of the war the Mlinister of Economic Affairs established numerous "War Production Boards" (Reiclssteller) for the control of various spheres of the German economy, namely, for (1) fodder, grain and other agricultural products, (2) animals and animal products, (3) fish, (4) fats and eggs, (5) esed, (6) garden-and.vineyard products, (7) forests and timbers, (\$) paper, (9) wrapping materials, (10) wood construction, (11) stone and earth, (12) glass, ceramics and wood-processing, (13) potash and salt, (14) coal, (15) iron and metals, (10) technical products, (17) production of machinery, (18) electrical products, (19) precision and optical instruments, (20) textiles, (21) clothing and related goods, (22) furs, (23) leather, (24) rubber, (25) chemicals, (26) industrials fats and cleansing materials, (27) fuel, (28) tobacco and coffee, (29) precious metals. In addition, he set up a "War Production Board" (Reichsstelle) for miceellancous commodities. As these "War Production Boards" were not able to deal directly with all the manufacturers and dealers, they delegated all or some of their functions to other agencies such as Economic Control Offices (Bexirtschaftungstellen) and Quotaholders (Fontingentstraeger). At the same time the Minister of Armament and War Production created for the control of the armament industry proper (Engere Ruestungsinduslric) Main Committees (Hauptaussehuesse), Main Rings (Hanptringe), Special Committees (Sondcratusschatesse), Special Rings (Sonderringe), Working Committees (Arbeilsausscliuesse) and Working Rings (Arbeitsringe) composed of engineers and technicians who were chosen from various enterprises. At the end of 1943 the Minister of Economic Affairs' jurisdiction of supervising all economic control except that over the armament industry proper was transferred to the Minister of Armament and War Production in large part becasuse a borderline between armament industry proper and armament industry no longer could be maintained. As a result of this transfer, the Minister of Armament and War Production created, in addition to the existing agencies, new agencies, namely, Main Production Committees (Produlutonst:ansz:anssschuesse) and Production Committees (Produklionsausschuesse). Armament Boards (Rutestungskommissionen), Armament Inspections (Ruestungsinspel:tionen) Armament Commands (Ruestungskommandos), Army District Delegates (Wehrhreisbeanffragte), District Delegates 
ones, whether to employ the Nazi technique of economic control ${ }^{99}$ or to set up new principles of control.

Under such circumstances it is self-evident that only a staff of highly qualified military and civilian officers will be able to solve these and many other problems. Knowledge of the language and of the political and economic structure of the enemy country will be prerequisites for the qualification of these officers. ${ }^{100}$ To supply them with broad lines of policy and with some, perhaps obsolete, guidebooks will not be sufficient.

(Bezirksbeauftragte) and Armament Chairmen (Ruestungsobmaenner) were charged with the supervision of factories and plants. In building up this complicated system of control the Ministers used the previously established organization of the entire German industry and trade into Reich Groups (Reichsgruppen), Economic Groups (Wirtschaftsgruppen), Trade Groups (Fachgruppen) and Trade Sub-Groups (Unterfachgruppen) for the purpose of appointing them Economic Control Offices, Quotaholders and Main Production or Production Committees.

99. Originally the so-called base period system was employed, i.e., the manufacturer was permitted to process a certain percentage of the raw material which he had used within a certain base period. Since this control system still permits production of non-essential goods, it was later abandoned. A great many " $L$ and $M$ Orders" were issued, in fact so many that they had to be revised and simplified at the end of 1942. In addition, the device of "universal'check" (Universalscheck) and "universal-transfer-certificate" (Universal-zlebertragutngsschein) was introduced by the head of the various "War Production Boards" in conformance with a decree issued by the Minister of Economic Affairs. Raw material was now allocated in form of a check issued by the War Production Board to the manufacturer. The latter endorses the check to the dealer from whom he wishes to obtain the material. The dealer may endorse the check to the producer who has either to preserve it or to turn it over to the War Production Board which had issued it. If the amount of raw material allocated to the manufacturer must be obtained from several dealers, the manufacturer may issue to them so-called "universal-transfer-certificates" (Universaluebertragungsscheine) on the strength of the check which he retains. Recently, the economic control procedure has been extremely tightened. Goods may be produced only on the basis of specific directives (Herstel lungsanweistungen).

100. The difficulty of finding qualified officers must not be underestimated. It should therefore be seriously considered to utilize the services of many of those experts who have come to the United States in recent years and whose loyalty to this country is beyond doubt. Some government agencies have availed themselves of this unique opportunity to some extent. Their experience with them has justified their policy. 